Article

\title{
Metrics of Urban Sustainability: A Case Study of Changing Downtowns in Thunder Bay, Canada
}

\author{
Todd Randall *, Trevor Kavalchuk and Reg Nelson \\ Department of Geography and the Environment, Lakehead University, 955 Oliver Road, Thunder Bay, \\ ON P7B 5E1, Canada; trkavalc@lakeheadu.ca (T.K.); rjnelson@lakeheadu.ca (R.N.) \\ * Correspondence: randall@lakeheadu.ca
}

Received: 18 April 2017; Accepted: 11 July 2017; Published: 19 July 2017

\begin{abstract}
Thunder Bay, a medium-sized city in Northern Ontario, has a twin downtown core model, arising from the merging of two former cities in 1970. Its north core, designated as the City's Entertainment District has received considerable investment, notably a major waterfront renewal project undertaken in 2009 as part of an overall strategy towards downtown revitalization. Greater diversity of commercial functions and increasing residential capacity in downtowns are considered positive steps towards sustainable urban development. It is hoped the leadership taken by the City in its downtown capital investments can stimulate others (corporations and individuals) to re-invest in both living and working in more central locations to the benefit of environmental sustainability indicators like journey-to-work (distance and mode selected) and residential density. This article tracks changes in business composition and residential capacity during a five year period via the development of an intensive database of business and institutional activities. Urban sustainability metrics developed include residential capacity and density, business vacancy rates and business composition and turnover, which complement an existing measure of land-use diversity developed in earlier research. While major capital investments in downtown revitalization (such as the waterfront project) have fairly long-term impact horizons, data suggest some positive trends in the developed metrics in the downtown north core since 2009. In particular, there have been notable investments in waterfront condos and downtown lofts and some diversification in the food retailing and restaurant sectors. However, overall trends in downtown commerce are currently flat, indicative of a struggling local economy and a continued suburbanization of key commercial sectors.
\end{abstract}

Keywords: land-use change detection; urban sustainability metrics; land-use diversity; downtown revitalization; urban renewal; Central Business District

\section{Introduction}

In the latter half of the 20th Century, a progressive decline in the overall health of downtown areas in North America has occurred [1,2]. There are numerous causes for this decline including but not limited to the decentralization of many traditional downtown functions to surrounding suburban areas and overall changes in the economic activity of a city or metropolitan area. With respect to the latter, larger cities in eastern North America have seen major declines in central cities or Central Business Districts (e.g., Detroit, Buffalo, Montreal) which can be attributed to declines in the manufacturing sector and coincidental rise of tertiary economic activities in the emerging high-tech economy and financial services industry [3]. However, deindustrialization and the growth of new economic activities do not necessarily occur in the same city or region. For smaller cities, situated in the resource-rich hinterland areas of Canada or the United States, changes in technology and global markets have affected employment in traditional job-rich sectors such as forestry, mining, fishing and agriculture. Some of these communities are now faced with real population decline requiring municipal governments to adjust their traditional planning mindset focused on economic 
and population growth [4]. With respect to the impact of suburbanization, residents began early in the 20th Century to migrate away from downtown areas [5] and this migration and explosion of housing in suburban rings is well documented for cities of a variety of scales [6]. Other traditional central city functions, such as commercial or retail activities followed in due course with the introduction of the regional shopping centre model in North America (in the 1960's and 1970's) and proliferation of the 'Big Box' retail sector since the late 1980s. Not all cities or metropolitan areas experienced these declines in their downtowns due to the combined effects of suburbanization and shifting economic functions. Examples such as New York or San Francisco in the United States and Toronto and Vancouver in Canada have, in general, maintained a healthy central city or downtown core even with substantial suburban growth, due to having enough overall investment and population growth [7].

Municipal governments were very much aware of the decline of downtowns and have experimented with a variety of renewal and revitalization strategies over the past half-century to maintain their function and viability. Such downtown renewal strategies fall into one of three categories, according to [6]: (1) adaptation for automobile accessibility; (2) head-on competition with suburbs, and (3) the accentuation of a distinct core area identity. The creation of downtown mall projects during the 1970s - probably the most well-known revitalization tool—is generally viewed as a failed attempt at revitalization, particularly in mid-sized cities [8], as are projects which prioritized automobile access to the core over accommodation of pedestrians, as a means for downtowns to compete with suburban areas [9]. More successful downtown renewal projects have been the creation of recreational facilities, stimulating residential (re-)occupancy in downtowns and construction of cultural facilities such as downtown sports arenas and convention centres [10,11]. An increasing area of urban renewal has been that of 'waterfront renewal', in which former industrial waterfront (or riverfronts) have been reclaimed and redeveloped as a means of city renewal $[12,13]$. As many of these waterfronts are adjacent to downtowns, they too provide significant potential to act as a catalyst of downtown revitalization.

\section{Project Objectives and Study Area}

This article presents a case study of the City of Thunder Bay's recent history with revitalization and renewal. Thunder Bay is a small to medium-sized city with a metropolitan population of approximately 121,600 [14], located in Northwestern Ontario. It has a total land area of $2556 \mathrm{~km}^{2}$ and an average population density of 47.6 persons $/ \mathrm{km}^{2}$. Thunder Bay was created in 1970 through the amalgamation of the two former cities of Port Arthur and Fort William, whose former Central Business Districts (CBDs) are now commonly referred to as the North Core and South Core, respectively (see Figure 1). At the time of amalgamation in 1970, the combined city's population was approximately 112,000 [15] and was forecast to grow considerably. However, during the 1970s and continuing, Thunder Bay faced many of the same challenges as other urban centers in Canada and the U.S., such as urban sprawl, declining industrial activity, and the decay of downtown and inner city neighbourhoods. Unique to Thunder Bay is the existence of two struggling downtown cores (rather than one in most cities), amidst the backdrop of a loss of well-paying blue collar employment in the forestry and grain-handling sectors since the 1990s.

Recognizing the challenge of managing two downtown cores in difficult economic times (the two former cities are only approximately $7 \mathrm{~km}$ apart), the City opted to better differentiate the roles of the two former CBDs through a process of 'urban specialization'; mentioned by [6] as one of 3 categories of downtown renewal strategies. The North Core has been re-branded as the City's 'Entertainment District' and, in addition to the location for the Waterfront renewal project, is home to a charity casino, Marina Park (which hosts several concerts and festivals annually), a playhouse, a growing diversity of bars and restaurants as well as other downtown functions like shopping and office employment. The South Core has been re-branded as the City's 'Business District' and houses City Hall and most of the city departments and divisions (i.e., planning, engineering, parks, etc.), federal government regional offices, a newly constructed Provincial courthouse (in 2014), an aging but valued arena (Fort William Gardens) and other downtown functions. The area between the two cores is known 
as the 'Intercity Area' and has been the location for much of the suburban commercial and light industrial development seen in the City since 1970. Growth of the Intercity Area was meant to unite the two cities both politically and economically $[16,17]$. Unfortunately, due to the above-mentioned economic challenges, investments in the Intercity-while practical in a spatial sense-have resulted in dis-investment in the older north and south cores. Two key sectors in which this trend has been noted are the insurance and financial sectors (see [18]). Traditionally and in many current cities these are core employment sectors located within the downtown core. Wilson's study in 2014 demonstrated a continued suburbanization of the insurance and financial services sectors to Thunder Bay's Intercity area over the past half-century (Figure 2). While these sectors were almost exclusively downtown in 1965 through to 1990 (e.g., 89\% in North and South cores in 1965; Table 1), slightly less than one-quarter of these functions are retained in the two downtowns as of 2013. This trend, like that observed in downtowns across North America further explains the downturn in the economic health and/or vibrancy of the two downtowns and challenges faced for revitalizing these areas.

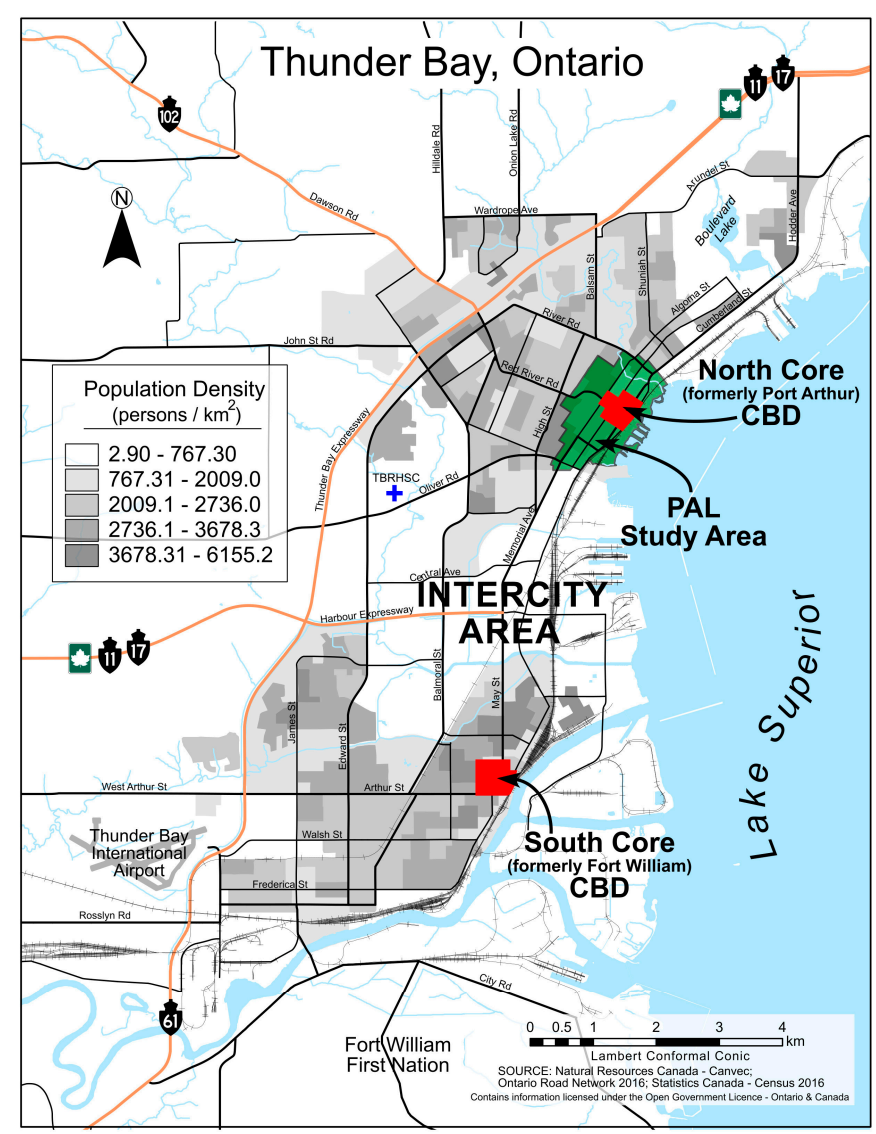

Figure 1. Study area for the Prince Arthur's Landing (PAL) project discussed in this article, located immediately adjacent to a major waterfront renewal project initiated in 2009.

Table 1. The total number of businesses in the Financial and Insurance sectors in the downtown and Intercity areas of Thunder Bay Ontario for the period 1965 to 2013 (derived from [18]).

\begin{tabular}{cccccccccc}
\hline \multirow{2}{*}{ Year } & \multicolumn{2}{c}{ North Core } & \multicolumn{2}{c}{ South Core } & \multicolumn{2}{c}{ Intercity } & \multicolumn{2}{c}{ Other } & \multirow{2}{*}{ Total } \\
\cline { 2 - 9 } & Tally & \% of Total & Tally & \% of Total & Tally & \% of Total & Tally & \% of Total & \\
\hline 1965 & 49 & $39 \%$ & 62 & $50 \%$ & 2 & $2 \%$ & 12 & $10 \%$ & 125 \\
1980 & 41 & $28 \%$ & 55 & $37 \%$ & 10 & $7 \%$ & 42 & $28 \%$ & 148 \\
1990 & 58 & $36 \%$ & 53 & $33 \%$ & 16 & $10 \%$ & 33 & $21 \%$ & 160 \\
2000 & 32 & $23 \%$ & 19 & $14 \%$ & 45 & $33 \%$ & 41 & $30 \%$ & 137 \\
2013 & 25 & $17 \%$ & 10 & $7 \%$ & 67 & $47 \%$ & 41 & $29 \%$ & 143 \\
\hline
\end{tabular}


It is important to acknowledge that downtown revitalization is not an attempt to return a city to the conditions of a previous period with a dominant downtown core. Rather, these are attempts to 'modernize' and 'retool' the downtown so it can remain an integral component of its overall metropolitan area in the context of more sustainable land use patterns in cities. Moreover, revitalization of downtown core areas should result in creating downtown environments that are enticing and walkable [19]. There is an increasing number of innovative planning concepts aimed at creating more sustainable metropolitan areas [20], including pedestrian-oriented and mixed-used development models of the New Urbanism [21,22], transit-oriented developments such as those now found in Portland and San Diego and other US cities [23-25], and the suburban downtown and regional town centre models found in Toronto and Vancouver, respectively (as discussed in [26,27]). Such 'new' strategies are largely replicating earlier models of urban form in North America and borrow heavily from European examples [28]. Whatever is planned and built in downtowns to achieve their revitalization, they are planned in the context of creating more sustainable communities in both the environmental and socio-economic interpretations of sustainability. In essence, good planning would result in greater vibrancy of core areas and be part of an integrated effort to lessen the overall negative effect of cities on the environment. Borrowing from Jane Jacobs' concept of 'exuberant diversity' [29], she wrote that four conditions are indispensable for a downtown core to be considered vibrant in the social and economic senses: (1) mixed primary uses; (2) small blocks; (3) aged buildings; and (4) concentration. Downtown cores are fortunate that they typically have both small blocks and aged buildings, something that is difficult to replicate in the postwar North American suburb. The other two conditions (mixed primary uses and concentration) are both core concepts of sustainable urban development in that residential neighbourhoods, downtown cores, suburban downtowns or even an 'edge city' (see [30]) need a mix of primary uses-so that people are drawn to these locations at a variety of times during the day and week-and these activities (residential, commercial, etc.) need sufficient concentration to make them 'work'. For example, there are density threshold requirements to sustain economically viable public transit [31]. Similarly, school boards need a certain number of students within a school's catchment zone to make its operation viable. Typical indicators of healthy and vibrant urban forms are therefore residential land-use metrics like density and dwelling type mix, and commercial measures such as business diversity, investment and business stability, which will be discussed later in the article.

Revitalization efforts as a means to offset the economic decline of its downtown cores are not new to Thunder Bay. There have been a number of revitalization projects over the years including, but not limited to: the Keskus Mall (built: 1974; demolished: 1999) and Ontario Lottery and Gaming Corporation Charity Casino (opened: 2000) and the various efforts of the Waterfront District (The Waterfront District BIA is also known as the City's Entertainment District (http: //www.lakesuperior.travel/TravelOntario/ThunderBay/WaterfrontBIA.aspx, accessed on 26 March 2017)) Business Improvement Area (BIA) committee. Since 2008, the City of Thunder Bay has been championing the redevelopment of a portion of the north core waterfront in the vicinity of the pre-existing Marina Park—an area known as Prince Arthur's Landing (or PAL). The waterfront area at PAL, adjacent to the downtown North Core, has long been used for a variety of purposes including recreational use, for special events such as the City's annual Blues Festival, as well as mooring for vessels and personal watercraft for tourists and local boaters. Marina Park was originally conceptualized within the 1967 Port Arthur Downtown Renewal Scheme (actual construction of the park was in 1979). While there were major investments in the downtown North Core prior to 2008, the major capital investments by the City and the private sector in Phase I of the waterfront project beginning in 2009 do appear to have much greater potential impact (economic spinoffs) than earlier unsuccessful attempts to stem the decline of the downtown core. Phase I of the project saw the addition of a restaurant, arts and multi-use facility, splash-pad and skating rink, two 6-story condominium buildings, a hotel, as well as updated landscaping and increased and updated mooring facilities for personal watercraft [32]. Phase I started in summer 2009 and was largely completed by the summer of 
2014 when the condominium buildings were ready for occupancy. The construction of the hotel at the waterfront has been delayed due to financial uncertainties but the foundation and footings are in place with an advertised completion of late 2018.

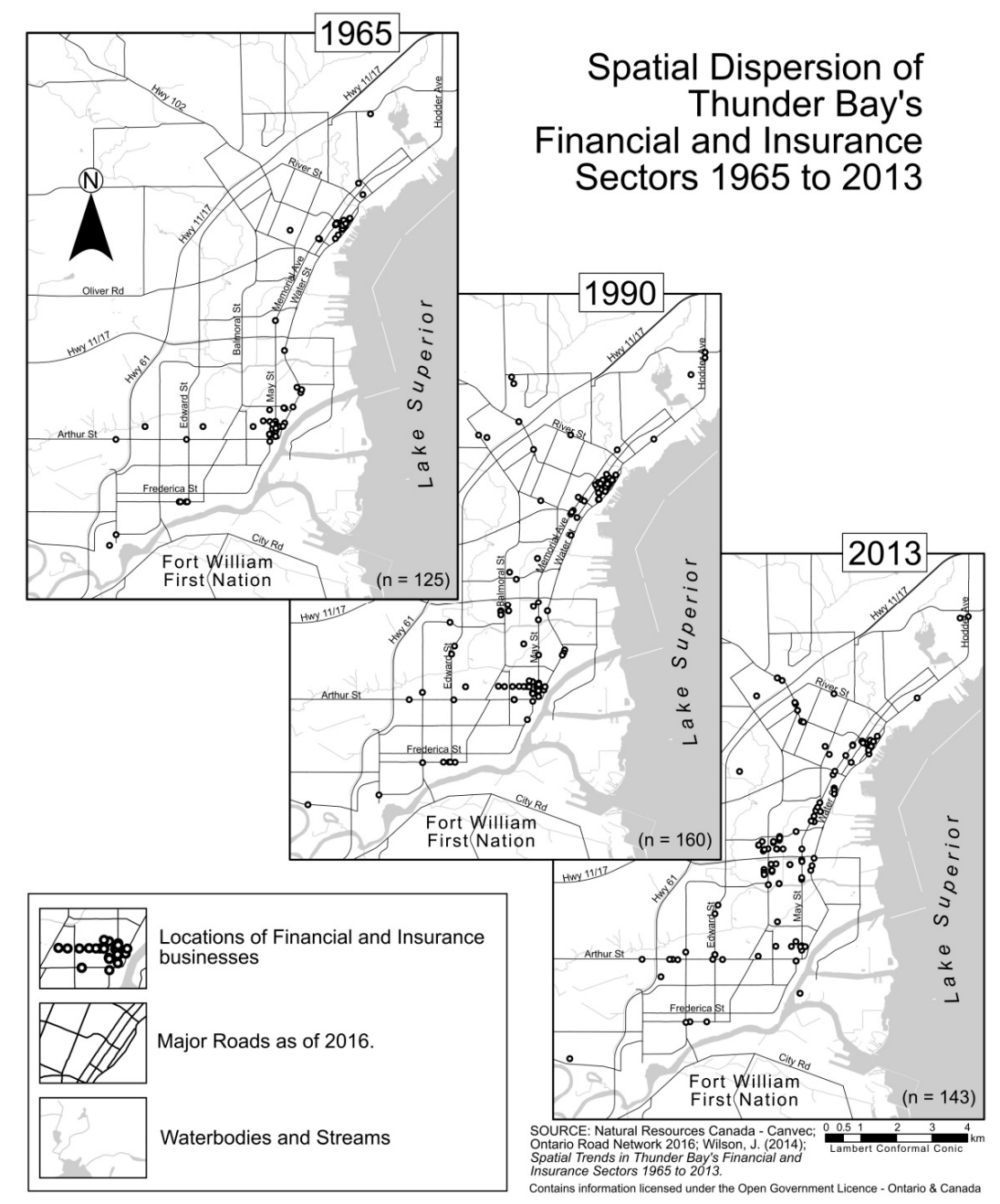

Figure 2. Spatial dispersion of the financial and insurance sectors in the City of Thunder Bay Ontario from 1965 to 2013 at three time periods. These sectors were traditionally located into one of the two downtown cores (North Core or South Core) but have gradually aggregated to the Intercity Area and other suburban locations. This figure, modified from [18] includes period prior to amalgamation in 1970 and up to a current sampling of businesses in 2013.

The overall purpose of the project discussed in this article is to track the changes in land use and business activity in the first five years since initiation and completion of Phase I of the PAL waterfront redevelopment project. A key outcome was to develop metrics of urban sustainability that capture the changes in the functional uses of the North Core downtown area. These metrics could then be applied in longer-term studies of urban changes occurring in Thunder Bay and in other jurisdictions. With the improvements to the waterfront at PAL, positive economic impacts observed in the adjacent downtown core, particularly influencing the viability and number of commercial and retail business functions, were expected. Moreover, with a residential component and a hotel to draw more tourists as part of the waterfront renewal, the project aimed to diversify the reasons for being at the waterfront beyond special events or festivals. Having people on site at a variety of times of day and for various reasons is one of the key criteria of Jacobs' term 'exuberant diversity' [29]. In anticipation of any of these potential positive impacts, data were collected to determine the building function and occupancy 
as well as residential occupancy within the downtown North Core. This data set is considered the baseline from which to assess temporal changes in residential and/or commercial activity coincident with investments by the City in the waterfront (PAL) and other downtown revitalization initiatives, and is in alignment with the City's goals towards urban sustainability [16,33]. The database collected in this study presents a unique opportunity to track the short- and long-term response of the downtown to this major capital investment by the City. A set of three metrics are presented that have been used to track residential occupancy and the commercial activity in the downtown core between 2010 and 2015 .

\section{Database Development and Metrics of Functional Change}

This section discusses the methods by which data were collected and databases formulated in 2010 and 2015. As stated elsewhere, the conceptual broad vision for the PAL waterfront project is the creation of a mixed-use area "that is people-friendly, visually inviting and diverse in building forms and functions. It mixes traditional design with innovation to create a safe, convenient and attractive neighbourhood" [32] (p. 2). Moreover the project is to reinforce existing and proposed linkages from the waterfront at PAL to the adjacent downtown, thereby affecting a positive economic impact on the North Core downtown and the City of Thunder Bay more broadly. A total of three metrics of functional change for the North Core downtown were developed in this project to capture the essence of this overall vision of a more diverse residential and commercial area: (1) residential capacity; (2) business composition; and (3) business turnovers (or stability). These metrics are then proposed as baseline sustainability indicators in tracking a more socially vibrant, healthy, and prosperous downtown core, better meeting principles of a more sustainable community described in [20]. It was decided a data sampling frequency of once in every five years would be appropriate due to the historically slow rate of changes observed in the City (e.g., relatively flat population growth since 2001 and economic challenges in primary resource economic sectors since the early 1990's [14,17]).

\subsection{Data Collection (2010 and 2015)}

The precise land-use, building function and dwelling occupancy of residential buildings within portions of downtowns zoned as Central Business District (CBD) are not well known. As permitted uses within land zoned as CBD in Thunder Bay are typically very broad, encompassing everything from Animal Care, Apartment Dwellings, Artisan's Workshop, ... to Retail Store, Retirement Residence, Shopping Centre or Townhouse Dwelling (e.g., as noted in zone "C5-Central Business District Zone" in the current Thunder Bay zoning bylaw [34] (p. 130)), a more detailed assessment was needed for the PAL study area in order to address the overall questions in this study, namely: what are specific buildings being used for and, therefore, how has building function and residential occupancy changed and what are the overall trends towards a more sustainable community. To address this need, in each of 2010 and 2015, land use and functional characteristics (business activities) of the north core downtown were documented and then used to create an associated geospatial database and photo archive. Data collected for each of the buildings and vacant land parcels in the study area were as follows:

- land use classification: land-use parcels classified as one, or more where applicable, of Commercial, Residential, Institutional, Industrial, or Open Space land use; it is commonly observed in downtown buildings to have multiple land-use designations where commercial or office functions occupy a ground-floor location in a building with residential dwellings (i.e., apartments or condos on the upper stories);

- residential building data (type, dwelling counts): buildings were determined as one of: single family home or detached dwellings; duplex or semi-detached dwellings; rowhouses; apartments-low-rise and high-rise buildings as well as apartments above stores; other data collected included \{the number of stories; the number of dwelling units $(\mathrm{du})$ \};

- for non-residential building data (building function): business or institutional functions were assigned a North American Industry Classification System (NAICS) code as described in [35] and 
then aggregated into the 10 amenity categories described by [36] and an additional category 11 (vacant building or vacant land parcel); other business data collected included: business name, address, services offered, school type (if applicable) and open space type (if applicable);

- photo archive of non-residential building frontages was also collected to allow for the detection of changes with time, especially since upgrades or updating of building facades are commonly incentivized by cities interested in improving the aesthetics and therefore attractiveness to prospective businesses.

The data collection in 2010 was carried out with a small group of senior undergraduate university students, each pair of students with a standardized protocol to collect field observations as noted above and to build a portion of the digital database. To make data collection more manageable and so that data could be collected by student pairings in a constrained period of time (during Fall 2010), the PAL study area was divided into 10 zones of approximately equivalent size (as shown in Figure 3). All of these data were reviewed by the authors for consistency amongst the student teams and a thorough process of data verification and standardization was then completed. The data collection in 2015 benefitted from 'lessons learned' from the previous sampling period and as such, the data collection was a much more streamlined process. As part of his thesis project, [37] re-sampled the 10 PAL zones of the 2010 data and created a verification process, allowing him to efficiently review the older database and update the various changes to residential building types, businesses present, etc. In all, the review, collection and creation of the 2015 database were completed over a 3 month period during Fall 2015. The total number of records in the 2010 database was 1606 which is the number of buildings in the sampled area; in these 1606 building polygons-a total of 432 individual business or institutional functions were identified. As mentioned earlier, since nearly all of the land in the North Core is fully built out, and due to the comparatively low rate of growth observed in the city, the database in 2015 is not considerably larger, having just 1611 building polygons (i.e., database records) housing a total of 441 individual business or institutional functions.

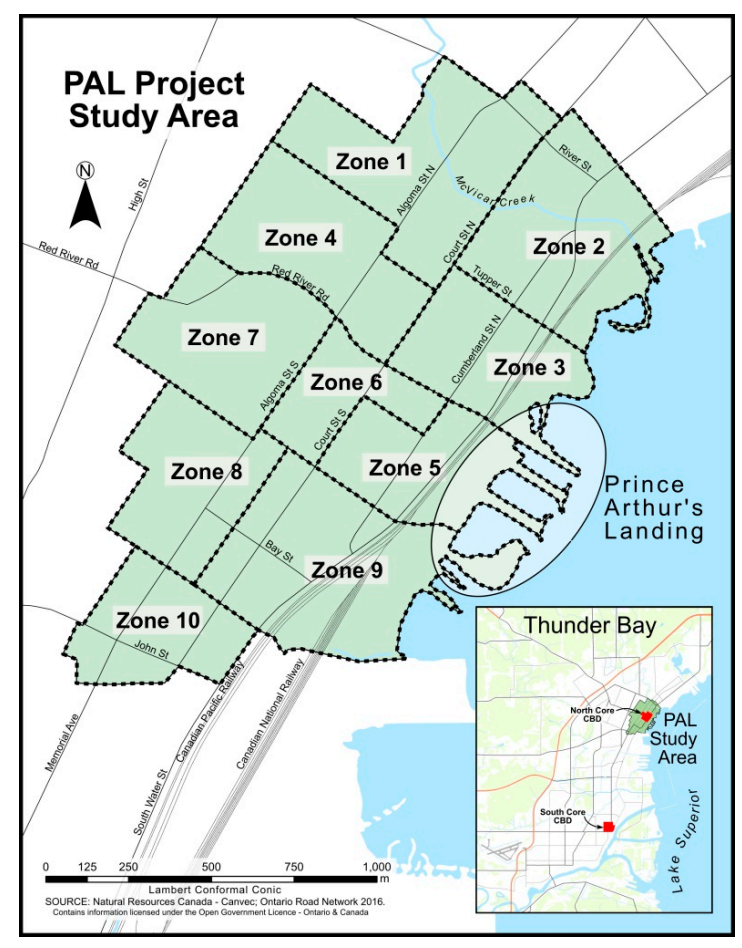

Figure 3. Division of the Prince Arthur's Landing (PAL) study area into 10 zones to enable data collection, analysis and mapping summary statistics and metrics. 
For the purposes of analysing trends in business and institutional functions in the North Core, all activities documented in non-residential buildings (totalling 432 records in 2010 and 441 records in 2015) were assigned a code according to the North American Industry Classification System (or NAICS) [35]. Ten categories of amenity diversity considered to be compatible with urban neighbourhoods were developed in [36], in consultation with the NAICS, including broad categories such as 'personal goods and services', 'household goods and services', 'healthcare goods and services', 'professional and technical services', 'government services', 'institutional facilities', 'tourism, entertainment and recreation', 'food and beverage retail', 'food services', and 'transportation goods and services'. The major business and institutional types found in the North Core as of 2015 are listed in Table 2, and represent approximately $60 \%$ of the 441 businesses and institutional functions present then. Those included on this list each account for at least 10 (of the 441) functions observed in the North Core downtown and include a range of personal goods and services (e.g., clothing, sporting goods, insurance companies, hair salons), health care goods and services (e.g., dentist, other health care practitioners), professional services (e.g., legal) and food services (e.g., full service restaurants, bars) (Table 2). These are typical traditional downtown functions. Conspicuously absent from this listing in Table 2 are banking and other financial institutions-typically very prominent components of a downtown. Financial institutions were observed to relocate away from the downtown core during the 1990s (Table 1) due to a change in land-use zoning in the City's more centralized Intercity area. The migration of these sectors away from the downtowns in Thunder Bay [18] was part of the overall economic decline in business activity that occurred during the past few decades which has left both downtown cores no longer the dominant location for banks, insurance agencies and other businesses in these sectors.

Table 2. Predominant business types present in Thunder Bay North Core as of 2015. Those included in this table had 10 or more distinct businesses sampled in 2015 and represented nearly $60 \%$ of all businesses in the North Core (this $60 \%$ includes a $13.2 \%$ vacancy rate, up from $10.6 \%$ in 2010 ).

\begin{tabular}{|c|c|c|c|c|}
\hline \multirow{2}{*}{$\begin{array}{l}\text { NAICS } \\
\text { Cat/Code }^{1}\end{array}$} & \multirow{2}{*}{ Description } & \multicolumn{2}{|c|}{ Businesses in 2015} & \multirow{2}{*}{ Amenity Category ${ }^{2}$} \\
\hline & & (Tally) & $(\%$ of PAL) & \\
\hline 448 & Clothing and clothing accessories stores (incl. jewellery) & 10 & $2.3 \%$ & (1) Personal Goods and Services \\
\hline 451 & $\begin{array}{l}\text { Sporting goods, bike, hobby, sewing, book, } \\
\text { art supplies and music }\end{array}$ & 16 & $3.6 \%$ & (1) Personal Goods and Services \\
\hline 453 & $\begin{array}{l}\text { Miscellaneous store retailers } \\
\text { (florist, stationery, gift, pet, u-brew) }\end{array}$ & 23 & $5.2 \%$ & (1) Personal Goods and Services \\
\hline 524 & Insurance carriers and related activities (ins. brokers) & 10 & $2.3 \%$ & (1) Personal Goods and Services \\
\hline 8121 & Personal care services (hair care, barber, salon, tanning) & 28 & $6.3 \%$ & (1) Personal Goods and Services \\
\hline 6212 & Offices of dentists & 13 & $2.9 \%$ & $\begin{array}{l}\text { (3) Healthcare Goods } \\
\text { and Services }\end{array}$ \\
\hline 6213 & $\begin{array}{l}\text { Offices of other health practitioners (chiropractors, } \\
\text { physiotherapists, optometry) and medical lab services }\end{array}$ & 18 & $4.1 \%$ & $\begin{array}{l}\text { (3) Healthcare Goods } \\
\text { and Services }\end{array}$ \\
\hline 6241 & Individual and family services (counselling) & 12 & $2.7 \%$ & $\begin{array}{l}\text { (3) Healthcare Goods } \\
\text { and Services }\end{array}$ \\
\hline 5411 & Legal services & 14 & $3.2 \%$ & $\begin{array}{l}\text { (4) Professional and } \\
\text { Technical Services }\end{array}$ \\
\hline 8131 & Religious organizations & 14 & $3.2 \%$ & $\begin{array}{l}\text { (4) Professional and } \\
\text { Technical Services }\end{array}$ \\
\hline 8134 & $\begin{array}{l}\text { Civic and Social Organizations } \\
\text { (incl. community and recreational ctrs) }\end{array}$ & 15 & $3.4 \%$ & $\begin{array}{l}\text { (4) Professional and } \\
\text { Technical Services }\end{array}$ \\
\hline 7221 & Full-service restaurants & 29 & $6.6 \%$ & (9) Food Services \\
\hline 7222 & Limited-service eating places (incl fastfood restaurants) & 12 & $2.7 \%$ & (9) Food Services \\
\hline 99992 & vacant building or storefront & 58 & $13.2 \%$ & (11) Vacant \\
\hline
\end{tabular}




\subsection{Metrics of Functional Changes in the North Core (2010-2015)}

A set of three functional change metrics were conceptualized to track progress on the City's vision for its North Core-a mixed-use area "that is people-friendly, visually inviting and diverse in building forms and functions" [32] (p. 2). The three metrics developed include: (1) residential capacity; (2) business composition; and (3) business turnovers (or instability). These metrics are specifically addressing the diversity in form and function of the downtown cores, tracking the changes in the residential component found in the downtown core and the number and diversity in business and other functions present. These metrics are proposed as baseline urban sustainability indicators in tracking a more socially vibrant, healthy, and prosperous downtown core.

\subsection{Functional Change Metric 1: Residential Building Capacity}

The pertinent residential data collected in 2010 and 2015 for this metric were dwelling count and dwelling type attributes described earlier. The total change in dwelling unit (du) counts for all PAL zones is an increase of $211 \mathrm{du}$ (or approximately $8 \%$ ) over the five year period (Table 3) and the overall gross residential density of the study area increased from $12.7 \mathrm{du} / \mathrm{ha}$ to $13.7 \mathrm{du} / \mathrm{ha}$. All PAL zones-except zone 3-experienced an increase in residential dwelling counts during the period with the more notable double-digit increases occurring in zones 1, 4, 5, 8, 9 and 10 (Table 3); the highest increases (120 dwellings added to zone 5; Figure 4) are those attributable to the construction of the two condominium buildings as part of the Waterfront renewal project and a private investment in a loft-conversion project along Cumberland Street in the downtown core $[38,39]$. The other notable increases in zones other than zones 5 and 8 (those larger than $10 \mathrm{du}$ ) in Table 3 are attributable either to 'dwelling unit conversions' or 'demolition and reconstruction' (Table 4) as there was no appreciable vacant land for construction of any dwellings, other than at the waterfront, identified in the 2010 database. Between 2010 and 2015, there is an overall decline of $54 \mathrm{du}($ or $-6.3 \%)$ in the number of single family (detached) homes and increases of $129 \mathrm{du}(+31 \%)$ and $3 \mathrm{du}(+10 \%)$ in the numbers of duplexes (semi-detached dwellings) and rowhouses, respectively (Table 4). The increases in apartment dwelling counts (133 du or $+10.3 \%$ ) are accounted mostly with the $120 \mathrm{du}$ added in zone 5 as mentioned immediately above.

Table 3. Changes in residential capacity (functional change metric 1) measured in Thunder Bay's North Core for the period 2010 to 2015.

\begin{tabular}{|c|c|c|c|c|c|}
\hline \multirow{2}{*}{ PAL Zone ${ }^{1}$} & \multicolumn{2}{|c|}{ Dwelling Unit Counts } & \multicolumn{2}{|c|}{ Change 2010-2015 } & \multirow{2}{*}{ Main Cause ${ }^{2}$} \\
\hline & 2010 & 2015 & $\mathrm{du}$ & $\%$ & \\
\hline 1 & 437 & 450 & 13 & $3.0 \%$ & $\mathrm{C}$ \\
\hline 2 & 209 & 211 & 2 & $1.0 \%$ & - \\
\hline 3 & 16 & 15 & -1 & $-6.3 \%$ & - \\
\hline 4 & 339 & 358 & 19 & $5.6 \%$ & C \\
\hline 5 & 186 & 306 & 120 & $64.5 \%$ & $\mathrm{~A}$ \\
\hline 6 & 76 & 84 & 8 & $10.5 \%$ & - \\
\hline 7 & 429 & 432 & 3 & $0.7 \%$ & - \\
\hline 8 & 243 & 264 & 21 & $8.6 \%$ & B \\
\hline 9 & 454 & 467 & 13 & $2.9 \%$ & $\mathrm{C}$ \\
\hline 10 & 217 & 230 & 13 & $6.0 \%$ & C \\
\hline Totals (all zones) & 2606 & 2817 & 211 & $8.1 \%$ & $A, B$ \& $C$ \\
\hline
\end{tabular}

\footnotetext{
${ }^{1}$ PAL zones $=$ Prince Arthur's Landing data collection zones as shown in Figure $3 .{ }^{2}$ For notable changes in dwelling unit counts $(>10 \mathrm{du})$, the main causes for changes in dwelling counts are attributable to one of the following (A, B or C): A: construction of 2 new condominium buildings during Phase I of waterfront renewal and a loft conversion project; B: construction of a new 21-unit three story apartment in the Bay-Algoma area; C: introduction of multi-unit dwellings on vacant lots or replacement of a single family home, the result of the modification of zoning in these neigbhourhoods to include a component of multi-unit (multi-family housing).
} 
Table 4. Changes in types of dwellings found in the Thunder Bay's North Core for the period 2010 to 2015. Statistics are aggregated for the 10 PAL zones indicated on Figure 3.

\begin{tabular}{ccccc}
\hline \multirow{2}{*}{ Dwelling Unit Type $^{\mathbf{1}}$} & \multicolumn{2}{c}{ Dwelling Counts } & \multicolumn{2}{c}{ Change } \\
\cline { 2 - 5 } & $\mathbf{2 0 1 0}$ & $\mathbf{2 0 1 5}$ & $\mathbf{( d u )}$ & $\mathbf{( \% )}$ \\
\hline Single Family Home & 862 & 808 & -54 & $-6.3 \%$ \\
Duplex & 416 & 545 & 129 & $31.0 \%$ \\
Rowhouse & 31 & 34 & 3 & $9.7 \%$ \\
Apartment & 1286 & 1419 & 133 & $10.3 \%$ \\
Total & $\mathbf{2 5 9 5}$ & $\mathbf{2 8 0 6}$ & $\mathbf{2 1 1}$ & $\mathbf{4 5 \%}$ \\
\hline
\end{tabular}

\footnotetext{
${ }^{1}$ Single family home (or detached) dwelling; Duplex includes 'side-side' duplex and single family homes converted to 'apartment duplex'; Apartment dwelling units includes those in low rise ( $<5$ stories) and high rise apartment buildings as well apartments dwellings located above street-level commercial or retail businesses.
}

Much of the increase in duplex dwellings is accounted for by 'dwelling unit conversion', which is fairly common in older city centres or downtown cores as a means to increase residential intensification [40]. A conversion is where a single family home is renovated into a multi-family dwelling unit by interior partitioning and additional exterior access doors to create what is called an 'apartment duplex' which has 2 dwellings per building. There are some examples in the study area in which a previous single family dwelling was demolished and replaced with a new structure as a single family home (i.e., a replacement), duplex or small apartment building. The additions of the latter two categories represent incremental residential 'intensification' of the neighbourhoods which is mandated within municipal and provincial planning documents such as the Provincial Policy Statement, the City's Official Plan and other planning or visioning documents at the municipal or provincial government level $[16,41,42]$. Such action towards intensification and better mixing of primary land uses, specifically residential and commercial activities, are essential in any city's plans towards a condition of greater urban sustainability [20]. Such mixing (or integration) of primary land uses will have positive benefits towards environmental sustainability with reductions in vehicular travel demand (i.e., enhanced pedestrian access between residential and non-residential destinations) and intensification such that population concentration is sufficient to meet thresholds of effective and fiscally viable public transit [31]. Causal factors for these changes in density and dwelling types observed are discussed later.

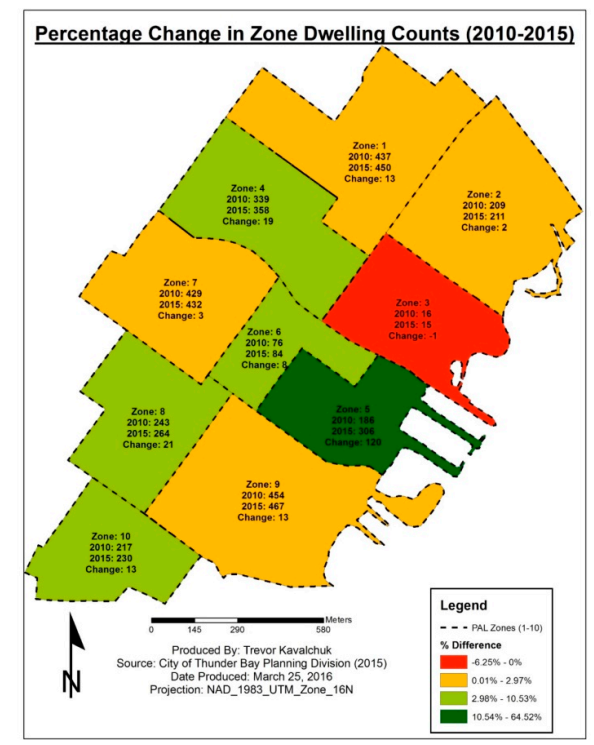

Figure 4. Count and percentage changes in residential capacity (functional metric 1) between 2010 and 2015. Notable addition of 120 dwellings to zone 5 is due to direct investments in condos at the waterfront and a loft conversion project. Percentage data shown using quantiles classification. 


\subsection{Functional Change Metric 2: Business Composition}

This second metric was conceptualized to track the changes in commercial and other non-residential activities in Thunder Bay's North Core. As was described earlier, data were collected for each of the non-residential buildings or vacant land parcels in each of 2010 and 2015 and then categorized using the NAICS [35]. Figure 5 shows an example of the types of changes in business function that were captured in the two databases. In this example, two types of business changes are noted: (1) at 220 Red River Road (extreme right in Figure 5), a restaurant occupies this building at both time periods, though there is a change in the restaurant's name; and (2) at 222 Red River Road (second from the right in Figure 5), the 2010 business (called 'Tenant's Choice' provided housing rental or leasing services) has vacated the building as of 2015. The relevant database records would show this latter example as a change from NAICS code 5311 (Lessors of real estate (property management companies)) in the 2010 database to a 'vacant building or storefront' in the 2015 database. As discussed earlier, each of these NAICS codes for all businesses and non-residential activities observed in the North Core downtown were assigned to the ten amenity categories as described by [36]. The example shown in Figure 5 depicts a total of four business addresses and is a more extreme example in which all four businesses changed between 2010 and 2015, with two of the four storefronts now vacant as of 2015. Of course, other portions of the downtown are more stable showing little to no change in business function over the five year period.
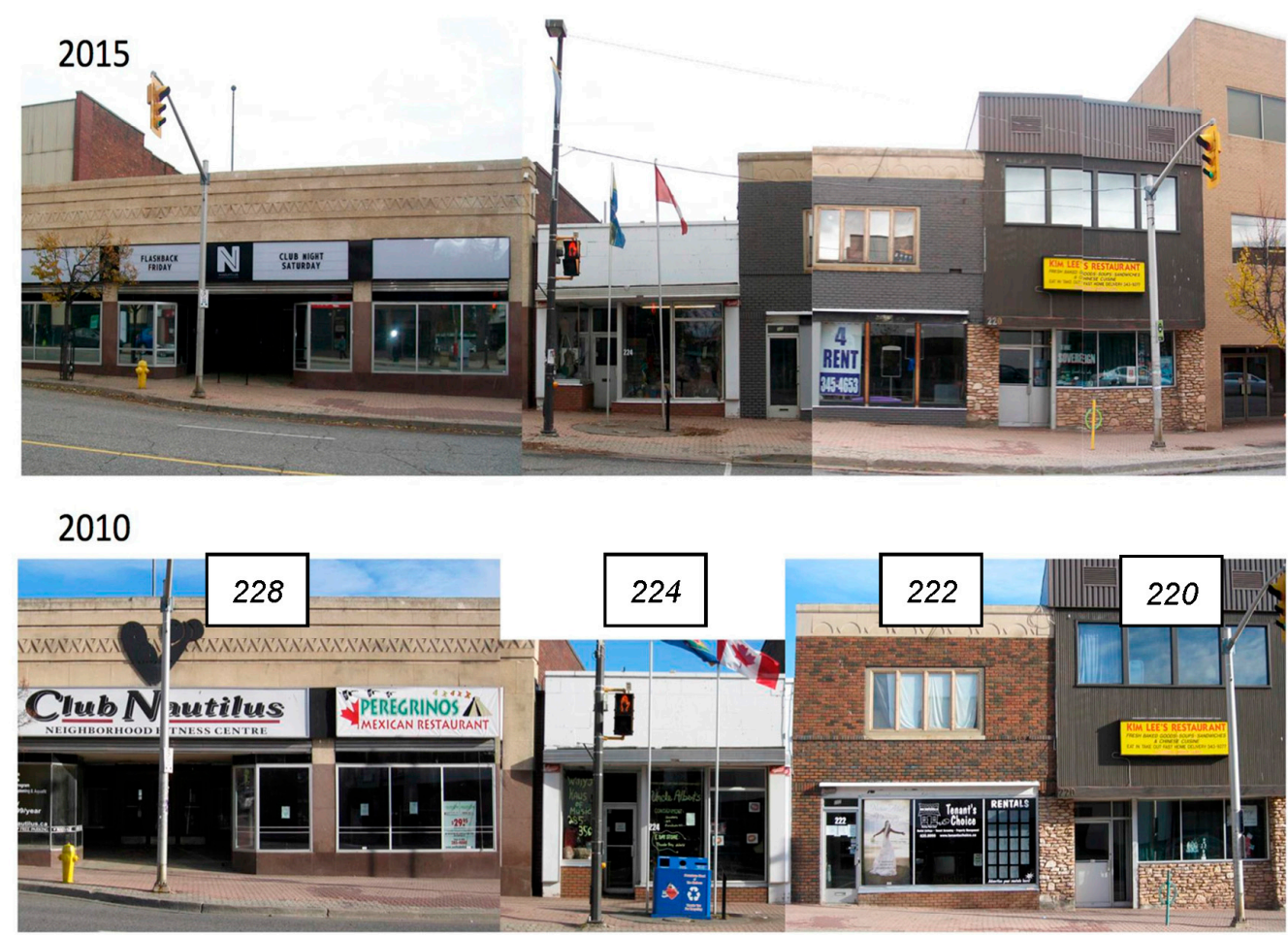

Figure 5. An example of the changes in business function between 2010 (bottom) and 2015 (top) identified in PAL zone 3 between addresses 220 and 228 Red River Road. Changes between 2010 and 2015 as follows: 220 (Kim Lee's Restaurant to the Sovereign Restaurant and Bar) 222 (Tenant's Choice-providing housing rental services to a vacant storefront); 224 (Willy J Antique Store to vacant storefront); 228 (vacant storefront-formerly Club Nautilus prior to NV Nightclub).

Overall, there is essentially little change in the total number of businesses over the 2010 to 2015 period (increasing from 432 to 441 business counts: Table 5) and there were no new non-residential buildings constructed. Any increases in business counts reflect a reconfiguration of existing building capacity. To try to isolate trends by major sectors, Table 5 only depicts business types that experience a 
change in business count (or tally) greater than or equal to three. Clearly, the most notable trend is the $26 \%$ increase in the number of vacant buildings or storefronts between 2010 and 2015 (an increase of 12 storefronts: Table 5) — there is also a small increase in vacant land parcels (3 new vacant parcels) due to building demolitions. In addition, business counts also increased for 'full-service restaurants', 'personal care services' (like hair and tanning salons), and 'heritage institutions' (like museums and art galleries). The growth in the service sectors (restaurants and other food and beverage providers) is corroborated by other media accounts of a resurgence in the downtown restaurant scene and other investments in Thunder Bay's North Core (or Entertainment District) [38]. With respect to declines in specific business types, a total of seven types experienced a decline in business counts of three or more specific businesses (Table 5). Amenity categories experiencing these notable declines between 2010 and 2015 included: personal goods and services (i.e., banking, clothing and clothing accessories); household goods and services (i.e., specialty trade contractors); professional and technical services (i.e., legal offices, computer systems design, other professional, scientific and technical services); and tourism, entertainment and recreation businesses (i.e., performing art companies). It appears these losses are the continuation of a trend of centralizing some traditional downtown functions (e.g., banks, clothing stores) away from either downtown core [18] into Thunder Bay's Intercity area, which is home to the City's major shopping mall (Intercity Mall) and most of its big box retail sector. Both these losses of diversity of businesses in the North Core (i.e., declines in 7 categories, increases in 3 categories, Table 5) and the overall increase in vacancy rates are negative sustainability trends.

Table 5. Changes in business composition (functional change metric 2) for the period 2010 to 2015 in the North Core. Only those business categories (NAICS Cat/Code) having changes of greater than 3 are included as these are deemed 'notable' for changes in business composition. This represents approximately $37 \%$ of the total number of businesses (i.e., 165 of 441 businesses).

\begin{tabular}{|c|c|c|c|c|c|c|}
\hline \multirow{2}{*}{$\begin{array}{c}\text { NAICS } \\
\text { Cat/Code }{ }^{1}\end{array}$} & \multirow{2}{*}{$\begin{array}{l}\text { Amenity } \\
\text { Category }{ }^{2}\end{array}$} & \multirow{2}{*}{ Description } & \multicolumn{3}{|c|}{ Business Counts } & \multirow{2}{*}{ Trend } \\
\hline & & & 2010 & 2015 & Change & \\
\hline 99992 & 11 & vacant building or storefront & 46 & 58 & 12 & Increase \\
\hline 7221 & 9 & Full-service restaurants & 24 & 29 & 5 & Increase \\
\hline 8121 & 1 & $\begin{array}{c}\text { Personal care services } \\
\text { (hair care, barber, salon, tanning) }\end{array}$ & 24 & 28 & 4 & Increase \\
\hline 712 & 1 & $\begin{array}{c}\text { Heritage institutions } \\
\text { (museums, art galleries) }\end{array}$ & 1 & 5 & 4 & Increase \\
\hline 6115 & 6 & Technical and trade schools & 0 & 3 & 3 & Increase \\
\hline 99991 & 11 & vacant land or lot (or 'vacant') & 0 & 3 & 3 & Increase \\
\hline 522 & 1 & $\begin{array}{l}\text { Credit intermediation and related } \\
\text { activities (banking) }\end{array}$ & 12 & 9 & -3 & Decline \\
\hline 238 & 2 & $\begin{array}{l}\text { Specialty trade contractors } \\
\text { (plumbing, heating, etc.) }\end{array}$ & 5 & 2 & -3 & Decline \\
\hline 5419 & 4 & $\begin{array}{l}\text { Other professional, scientific and technical } \\
\text { services (incl. vet, photo developing) }\end{array}$ & 3 & 0 & -3 & Decline \\
\hline 711 & 7 & Performing art companies (incl. theatres) & 5 & 2 & -3 & Decline \\
\hline 448 & 1 & $\begin{array}{l}\text { Clothing and clothing accessories stores } \\
\text { (incl. jewellery) }\end{array}$ & 14 & 10 & -4 & Decline \\
\hline 5411 & 4 & Legal services & 18 & 14 & -4 & Decline \\
\hline \multirow[t]{3}{*}{5415} & 4 & $\begin{array}{l}\text { Computer systems design and } \\
\text { related services }\end{array}$ & 6 & 2 & -4 & Decline \\
\hline & & sub-total (above categories only) & 158 & 165 & $\mathbf{n} / \mathbf{a}$ & $\mathbf{n} / \mathbf{a}$ \\
\hline & & total (all business categories) & 432 & 441 & $\mathbf{n} / \mathbf{a}$ & $\mathbf{n} / \mathbf{a}$ \\
\hline
\end{tabular}

${ }^{1}$ These are business type codes as noted in the North American Industrial Classification System [35]. ${ }^{2} \mathrm{~A}$ total of ten categories of amenities were created by [36] in their GIS-based Land-use Diversity Index (LDI) to quantify the diversity of business and other functions present in the residential neighbourhoods they described. 


\subsection{Functional Change Metric 3: Business Turnover}

This third metric builds upon the previous one, in that it also tracks changes in business activities. Different, however, is that it is a more precise tracking at the nature of changeovers in business functions using a change detection matrix approach. It indicates which categories of businesses have some stability or 'staying power' and which seem to change more frequently. A change detection matrix was derived at the level of the amenity categories as described by [36]. It is felt that in aggregating businesses into these categories it would be conceivable to track major changes in business function and especially the entrance or departure of key sectors from the downtown in the context of changing vacancy rates. As noted earlier, data were collected at a finer resolution captured and coded using NAICS codes so it would be possible to determine very precise changes. However, with only 448 records in the 2015 database, there is too much dispersion of the data across the 97 NAICS codes so it would be difficult to clearly see the trends - these overall trends are more apparent where the records were aggregated using the ten amenity classifications.

A change detection matrix was completed for all building in the two PAL databases to identify how categories of business and other institutional functions changed during the 2010 to 2015 period (Table 6). To ensure accurate results, building names and functions needed to be identically recorded in the databases - this had been completed as part of the database standardization and verification steps described earlier. Over the five year period, the majority (77\%) of business activities remained within the same amenity category in both sampling periods (Table 6). This is a notable result in that three-quarters of all commercial and institutional activities within the downtown North Core remained consistent across the period.

Table 6. Change detection matrix of business and institutional functions in the North Core for the 2010 to 2015 period. The sum of the unchanged functions (i.e., cell values on the diagonal) is 332 businesses (or $77 \%$ of the 432 businesses present in 2010). Those cell counts three or larger (highlighted in grey) are discussed in the accompanying text.

\begin{tabular}{|c|c|c|c|c|c|c|c|c|c|c|c|c|c|}
\hline & \multicolumn{13}{|c|}{ To Amenity Category in 2015} \\
\hline & & 1 & 2 & 3 & 4 & 5 & 6 & 7 & 8 & 9 & 10 & 11 & $\sum_{2010}$ \\
\hline \multirow{12}{*}{ 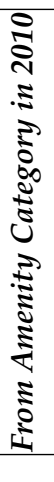 } & 1 & 88 & 0 & 1 & 2 & 0 & 2 & 4 & 1 & 4 & 0 & 11 & 113 \\
\hline & 2 & 7 & 17 & 1 & 0 & 0 & 0 & 0 & 0 & 0 & 1 & 3 & 29 \\
\hline & 3 & 2 & 1 & 51 & 0 & 1 & 0 & 0 & 0 & 0 & 0 & 3 & 58 \\
\hline & 4 & 3 & 4 & 2 & 32 & 0 & 1 & 0 & 0 & 1 & 0 & 9 & 52 \\
\hline & 5 & 0 & 0 & 1 & 0 & 12 & 0 & 0 & 0 & 0 & 0 & 2 & 15 \\
\hline & 6 & 0 & 0 & 0 & 1 & 0 & 22 & 0 & 0 & 0 & 0 & 2 & 25 \\
\hline & 7 & 1 & 0 & 0 & 2 & 0 & 1 & 32 & 0 & 0 & 0 & 1 & 37 \\
\hline & 8 & 1 & 0 & 0 & 0 & 0 & 0 & 0 & 16 & 1 & 0 & 1 & 19 \\
\hline & 9 & 1 & 0 & 1 & 1 & 0 & 0 & 0 & 0 & 35 & 0 & 3 & 41 \\
\hline & 10 & 0 & 0 & 0 & 0 & 0 & 0 & 0 & 0 & 0 & 6 & 0 & 6 \\
\hline & 11 & 8 & 0 & 2 & 0 & 1 & 2 & 2 & 0 & 3 & 0 & 21 & 39 \\
\hline & $\sum_{2015}$ & 111 & 22 & 59 & 38 & 14 & 28 & 38 & 17 & 44 & 7 & 56 & $\ldots$ \\
\hline
\end{tabular}

The categories of amenities were created by [36] to quantify the diversity of business and other functions present in the residential neighbourhoods they described; These are: (1) Personal Goods and Services; (2) Household Goods and Services; (3) Healthcare Goods and Services; (4) Professional and Technical Services; (5) Government Services; (6) Institutional Facilities; (7) Tourism, Entertainment and Recreation; (8) Food and Beverage Retail; (9) Food Services; (10) Transportation Goods and Services; and (11) Vacant s building or storefront or vacant land parcel.

However, there were notable changes (approximately 23\%) amongst the various amenity categories (Table 6). The most significant changes have been the overall increase in vacant buildings and storefronts increasing from 39 to 56 buildings (category 11 in Table 6). The main contributors to this increase in the overall vacancy rate have been declines in the number of businesses in two categories: personal goods and services (11 business closures) and professional and technical services ( 9 business closures), seeing a combined closure of 20 businesses between them over the 2010-2015 period. This 
loss in personal goods and services (category 1 ) is stemmed by a corresponding re-occupancy of vacant storefronts/buildings (i.e., 8 vacant storefronts converted to category 1 ). The overall net effect for category 1 is relatively flat (i.e., a total number of 113 businesses in 2010 versus 111 in 2015) due to other flows between the other amenity categories. Two amenity categories for which notable declines were observed between 2010 and 2015 are for category (2): household goods and services and (4) professional and technical services, with business count declines of $24 \%$ ( 29 to 22 businesses) and $27 \%$ (52 to 38 businesses), respectively (Table 6). Specific businesses in these categories either closing permanently or relocating out of the North Core during the period were: category 2 (specialty trade contractors-plumbing, heating, etc.) and category 4 (legal services, computer systems design, and other professional, scientific and technical services) that were identified earlier (Table 5). Like the business composition metric, the increase in vacancy rates is a negative sustainability trend as are the two amenity categories ( 2 and 4 in Table 6 ) which had notable declines. In contrast, positive trends observed in the period is the overall net increase in category (9) food services (Table 6) due to the increase of $20 \%$ in full service restaurants ( 24 to 29 businesses: Table 5 ).

\section{Discussion and Conclusions}

This study has presented three metrics as urban sustainability indicators to capture the changes in functional land-use (i.e., residential occupancy and business activities) in Thunder Bay's North Core between 2010 and 2015. These metrics are: (1) residential capacity; (2) business composition; and (3) business turnovers. Together they provide a means to track progress in the City's North Core downtown in response to the City-led initiative on waterfront renewal at Prince Arthur's Landing (PAL). Broadly stated, the objective of the PAL waterfront project is the creation of a mixed-use area "that is people-friendly, visually inviting and diverse in building forms and functions" [32] (p. 2) with the hope it would have a positive economic impact on the immediately-adjacent downtown. The above-mentioned metrics speak very directly to the measurement of economic impacts (with a focus on urban sustainability), such as business composition (or diversity) present in the core and business stability. Moreover, the residential capacity metric has captured both an increase in residential occupancy directly as part of the waterfront project (i.e., 2 condominium buildings added in PAL zone 5, Figure 3) as well as other increases in residential occupancy across the downtown core. Various intensification strategies such as loft conversions of aged buildings, construction of small apartments and other multi-unit residential buildings, as well as the conversion of a notable number of single family dwellings to apartment duplex dwellings, were noted in this study (Table 3; Figure 4). Facilitating the addition of more multi-unit residential buildings were the 2010 changes to the City's zoning with the re-introduction of mixed-use zones (MU1 and MU2; [34]), which have been assigned to areas surrounding the downtown core and elsewhere across the City previously zoned as exclusively single family detached (R1) or mixed housing detached and semi-detached (R2) housing. These intensification projects, some directly the result of the PAL waterfront project (i.e., condo buildings) and others in response from private investors and a change in city permissions (i.e., zoning) have led to a notable increase in gross residential density in the North Core from $12.7 \mathrm{du} / \mathrm{ha}$ (in 2010) to $13.7 \mathrm{du} / \mathrm{ha}$ (in 2015). Having an increased number of residents living downtown provides direct benefits to downtown businesses and is clearly in alignment with city goals of creating vibrant and diverse mixed-use communities [33], and has allowed the City to realize measurable action towards intensification and a better mixing of mixed primary land uses as articulated in the Provincial Policy Statement [42].

While the residential capacity metric has shown a positive trend from 2010 to 2015, the same cannot be said for the other two business-themed sustainability metrics. The overall trend in business composition over the five year period shows an increase in building vacancy and no new commercial buildings built during the period. Most business sectors have seen small changes during the period and the overall rate vacancy rate is $13.2 \%$ as of 2015 (58 of 441 storefronts vacant; Table 5), an increase from $10.6 \%$ in 2010 . The food retail and restaurant business sector is the only one seeing a modest 
increase during the period and reflective of a growing recognition of a downtown bar and restaurant scene as part of the North Core's branding as the City's 'Entertainment District'. However, the loss of traditional downtown functions such as clothing retailers, financial services (such as banks), insurance companies and other professional services has continued, which are relocating to the City's Intercity area and more suburban locales. This loss of business diversity in the downtown North Core-a move away from the traditional downtown functions-is interpreted as a negative trend with respect to urban sustainability and has a net negative effect on the vibrancy of the downtown core.

Despite the current state of the commercial sector in Thunder Bay, the longer-term prospects in the North Core are encouraging with the City's continued focus on strengthening and revitalizing its two downtown cores. Important in such revitalizations efforts is the differentiation of the North and South cores, as the 'Entertainment District' and 'Business District' respectively, so that they can both flourish in the current economic reality in which they are situated. The metrics developed in this initial five year period following the initiation of the waterfront renewal project at Prince Arthur's Landing will be part of a long-term assessment of this and other efforts by the City over the coming years. These metrics capture data not typically well-documented in downtown cores, yet are accessible and easy-to-understand metrics by which the community can track progress on its goals towards economic well-being and other sustainability goals liked mixed-used, pedestrian-oriented and socially-vibrant districts with sufficient density to support local amenities such as schools and public transit. This study has presented a novel dataset and conceptualized three metrics, which together represents a new approach to assessment of urban sustainability in a downtown core. The approach presented here could be adopted by any jurisdiction interested in tracking changes in residential capacity and/or commercial activities in response to revitalization strategies they may be undertaking. The frequency of database sampling (five years in this study) would need to be shortened in places experiencing a greater rapidity of urban growth than has been observed in the current study.

Acknowledgments: Assistance from various undergraduate students in the collection of the 2010 data is gratefully acknowledged, and we thank Jessica Wilson for the use of her project's data in the creation of Figure 2. We would also like to thank the City of Thunder Bay, Land Information Ontario, Statistics Canada and Natural Resources Canada for geospatial data used to create the maps. We also thank the three anonymous referees whose comments have improved the manuscript.

Author Contributions: Todd Randall conceptualized this long-term study on Thunder Bay's two downtown cores and collected the 2010 database with a class of senior students. Reg Nelson and Todd Randall verified and polished the 2010 database. Trevor Kavalchuk collected the 2015 database and, together with Todd Randall, analyzed the changes between 2010 and 2015 and conceived the sustainability metrics. Todd Randall wrote the manuscript; figures were created by Reg Nelson (Figures 1-3) and Trevor Kavalchuk (Figures 4 and 5).

Conflicts of Interest: The authors declare no conflict of interest.

\section{References}

1. Robertson, K.A. Downtown redevelopment strategies in the United States: An end-of-the-Century assessment. J. Am. Plan. Assoc. 1995, 61, 429-437. [CrossRef]

2. Faulk, D. The process and practice of downtown revitalization. Rev. Policy Res. 2006, 23, 625-645. [CrossRef]

3. Hartshorn, T.A. Interpreting the City: An Urban Geography; Wiley: New York, NY, USA, 1992; p. 484.

4. Simmons, J.; Bourne, L.S. Living with population growth and decline. Plan. Can. 2007, 47, 13-21.

5. Harris, R. Unplanned Suburbs: Toronto's American tragedy, 1900 to 1950; John Hopkins University Press: Baltimore, MA, USA, 1999; p. 356.

6. Filion, P.; Hoernig, H.; Bunting, T.; Sands, G. The successful few: Healthy downtowns of small metropolitan regions. J. Am. Plan. Assoc. 2004, 70, 328-343. [CrossRef]

7. England, K.; Mercer, J. Canadian cities in continental context: Global and continental perspectives on Canadian urban development. In Canadian Cities in Transition: Local through Global Perspectives; Bunting, T., Filion, P., Eds.; Oxford University Press: Don Mills, ON, Canada, 2006; pp. 24-39.

8. Filion, P.; Hammond, K. The failure of shopping malls as a tool of downtown revitalization in mid-size urban areas. Plan. Can. 2006, 46, 49-52. 
9. Rubino, A. Downtown Revitalization: The Hamilton Experience. Master's Thesis, University of Waterloo, Waterloo, ON, Canada, 2016.

10. Robertson, K.A. Downtown retail revitalization: A review of American redevelopment strategies. Plan. Perspect. 1997, 12, 383-401. [CrossRef]

11. Chapin, T. Beyond the entrepreneurial city: municipal capitalism in San Diego. J. Urban Aff. 2002, $24,565-581$. [CrossRef]

12. Marshall, R. Remarking the image of the city: Bilbao and Shanghai. In Waterfronts in Post-Industrial Cities; Marshall, R., Ed.; Spon Press: New York, NY, USA, 2001; pp. 53-73.

13. Millspaugh, M.L. Waterfronts as catalysts for city renewal. In Waterfronts in Post-Industrial Cities; Marshall, R., Ed.; Spon Press: New York, NY, USA, 2001; pp. 74-85.

14. Statistics Canada. Census of Canada Population; Statistics Canada: Ottawa, ON, Canada, 2016. Available online: http:/ / www12.statcan.gc.ca/census-recensement/2016/dp-pd/prof/index.cfm?Lang=E (accessed on 26 March 2017).

15. Statistics Canada. Census of Canada Population; Statistics Canada: Ottawa, ON, Canada, 1971.

16. Earthwise Thunder Bay. EarthWise Thunder Bay Community Environmental Action Plan: A Living Document. 2008. Available online: http://www.thunderbay.ca/assets/earthwise+assets/docs/5725 (accessed on 10 July 2017).

17. Randall, T.; Lorch, B. Planning challenges in Thunder Bay: optimism amongst demographic and economic shifts. Plan. Can. 2007, 47, 26-29.

18. Wilson, J. Spatial Trends in Thunder Bay's Financial and Insurance Sectors 1965 to 2013. Bachelor's Thesis, Department of Geography and the Environment, Lakehead University, Thunder Bay, ON, Canada, 2014; p. 101.

19. Canadian Urban Institute. The Value of Investing in Canadian Downtowns (Part 1-2011 and Part 2-2013). Available online: http:/ / www.downtowns360.ca/reports/ (accessed on 19 July 2017).

20. Rees, W.E.; Roseland, M. Sustainable communities: planning for the 21st Century. Plan. Can. 1991, 31, 15-26.

21. White, S.S.; Ellis, C. Sustainability, the environment, and New Urbanism: An assessment and agenda for research. J. Archit. Plan. Res. 2007, 24, 125-142.

22. United States Green Building Council (USGBC). Leadership in Energy and Environmental Design (LEED) for Neighborhood Development Rating System; United States Green Building Council: Washington, DC, USA, 2009; p. 144.

23. Poulsen, T.M. Shaping and managing Portland's metropolitan development. In Portland's Changing Landscape; Price, L.W., Ed.; Occasional Paper No. 4, Prepared for the Annual General Meeting of the Association of the American Geographers; Department of Geography, Portland State University: Portland, OR, USA, 1987; pp. 86-98.

24. Calthorpe, P. The Next American Metropolis: Ecology, Community and the American Dream; Princeton Architectural Press: New York, NY, USA, 1993; p. 175.

25. Dittmar, H.; Ohland, G. The New Transit Town: Best Practices in Transit-Oriented Development; Island Press: Washington, DC, USA, 2004.

26. Gad, G.; Matthew, M. Central and suburban downtowns. In Canadian Cities in Transition: The Twenty-First Century; Bunting, T., Filion, P., Eds.; Oxford University Press: Don Mills, ON, Canada, 2000; pp. 248-271.

27. Filion, P.; Gad, G. Urban and suburban downtowns: Trajectories of growth and decline. In Canadian Cities in Transition: Local through Global Perspectives; Bunting, T., Filion, P., Eds.; Oxford University Press: Don Mills, ON, Canada, 2006; pp. 171-191.

28. Beatley, T. Green Urbanism: Learning from European Cities; Island Press: Washington, DC, USA, 2000; p. 308.

29. Jacobs, J. The Death and Life of Great American Cities; Random House: New York, NY, USA, 1961.

30. Garreau, J. Edge City: Life on the New Frontier; Doubleday: New York, NY, USA, 1991; p. 546.

31. Pushkarev, B.S.; Zupan, J.M. Public Transportation and Land Use Policy; Indiana University Press: Bloomington, MN, USA, 1977.

32. Brook Mcllroy Planning \& Urban Design and Pace Architects. Prince Arthur's Landing at Marina Park-Executive Summary: Master Site Plan and Urban Design Guidelines. Available online: http:/ / www.thunderbay.ca/Assets/_thunderbayassets/docs/waterfront/Executive+Summary+ of+the+Master+Plan+\$!26+Urban+Design+Guidelines+for+PAL.pdf (accessed on 10 July 2017). 
33. EarthCare Thunder Bay. Thunder Bay Sustainability Plan. 2014-2020; EarthCare Thunder Bay: Thunder Bay, ON, Canada, 2014; p. 66.

34. City of Thunder Bay. Zoning By-law 100-2010. Available online: http://www.thunderbay.ca/Assets / City+Government/Departments/Dept+-+Dev+Services/docs/New+Zoning+By-law /Zoning+By-law+ January+13\$!2c+2013.pdf (accessed on 5 April 2017).

35. Statistics Canada. North American Industry Classification System; Catalogue No. 12-501-XIE; Ministry of Industry: Ottawa, ON, Canada, 2007.

36. Randall, T.A.; Baetz, B.W. A GIS-based land use diversity index model to measure the degree of suburban sprawl. Area 2015, 47, 360-375. [CrossRef]

37. Kavalchuk, T. Functional Land-Use Change in Thunder Bay's North Core between 2010 and 2015 Ascribed to Waterfront and Downtown Renewal Efforts. Bachelor's Thesis, Department of Geography and the Environment, Lakehead University, Thunder Bay, ON, Canada, 2016.

38. Ross, I. Thunder Bay's North Core Sees Reinvestment. Available online: https://www. northernontariobusiness.com/regional-news/thunder-bay/thunder-bays-north-core-sees-reinvestment369518 (accessed on 4 April 2017).

39. Ross, I. Condos, Hotel Construction Begins on Thunder Bay Waterfront. Available online: https: / www.northernontariobusiness.com/industry-news/design-build/condos-hotel-constructionbegins-on-thunder-bay-waterfront-369200 (accessed on 4 April 2017).

40. Larkham, P.J.; Jones, A.N. Strategies for increasing residential density. Hous. Stud. 1993, 8, 83-97. [CrossRef]

41. City of Thunder Bay. City of Thunder Bay Official Plan. Available online: http://www.thunderbay.ca/ Assets/_thunderbayassets/docs/planning/1721.pdf (accessed on 10 July 2017).

42. Province of Ontario. Provincial Policy Statement (PPS). Available online: http://www.mah.gov.on.ca/ Page215.aspx (accessed on 10 July 2017).

(C) 2017 by the authors. Licensee MDPI, Basel, Switzerland. This article is an open access article distributed under the terms and conditions of the Creative Commons Attribution (CC BY) license (http:/ / creativecommons.org/licenses/by/4.0/). 